December 2017 Volume 5 Issue 10

www.joucer.com

http://dergipark.gov.tr/jcer

Research Article

\title{
Determination of the Relationship Between Information Technology, Student Emotions and Science Literacy in the Light of Emotional Intelligence
}

\section{Volkan Hasan KAYA ${ }^{1}$ iD \\ ${ }^{1}$ University of Bremen, Institute of Science Education, Department Biology Education, Bremen, GERMANY, volk.has.an@gmail.com}

\begin{tabular}{|c|c|}
\hline Article Info & Abstract \\
\hline $\begin{array}{l}\text { Received: } \quad \text { January 01, } 2017 \\
\text { Accepted: } \quad \text { July 28, 2017 } \\
\text { Online: } \quad \text { December 03, } 2017 \\
\text { Keywords: Science, PISA, } \\
\text { Technology, Information Technology, } \\
\text { Emotional Intelligence }\end{array}$ & $\begin{array}{l}\text { In this study, it is aimed to determine the relationship between student } \\
\text { characteristics related to information technology, the emotions of } \\
\text { students and science literacy. Descriptive research model was used. The } \\
\text { sample of the study consists of } 589515 \text {-year old students in Turkey. As } \\
\text { a research instrument, the researchers used the results of cognitive tests } \\
\text { utilized by PISA in } 2015 \text { to assess students' science literacy skills. In this } \\
\text { study, Turkish students are divided into } 2 \text { groups. One of these groups } \\
\text { who respond all questions about student characteristics (High Emotional } \\
\text { Intelligence) and another who does not respond all questions about them } \\
\text { (Low Emotional Intelligence). It was found that the students with higher } \\
\text { emotional intelligence have higher science literacy. The results show that } \\
\text { the emotions of the students, the information technology that students } \\
\text { have at home and the increase the number of this technology positively } \\
\text { affect the science literacy. }\end{array}$ \\
\hline
\end{tabular}

open $\bigcirc$ access (a) CrossMark Cc

To cite this article: Kaya, V. H. (2017). Duygusal Zekanın Işı̆̆ında Bilişim Teknolojisi ve Öğrenci Duygularının Fen Bilimleri Okuryazarlığ 1 ile İlişkisinin Belirlenmesi. Journal of Computer and Education Research, 5 (10), 194-217. https://doi.org/10.18009/jcer.286268

\section{Duygusal Zekanın Işı̆̆ında Bilişim Teknolojisi ve Öğrenci Duygularının Fen Bilimleri Okuryazarlığı ile İlişkisinin Belirlenmesi}

\begin{tabular}{|c|c|}
\hline Makale Bilgisi & Öz \\
\hline $\begin{array}{l}\text { Geliş: } \quad 01 \text { Ocak } 2017 \\
\text { Kabul: } \quad 28 \text { Temmuz } 2017 \\
\text { Yayın: } \quad \text { 03 Aralık } 2017 \\
\text { Anahtar kelimeler: Fen eğitimi, } \\
\text { PISA, Teknoloji, Bilişim Teknolojileri, } \\
\text { Duygusal Zekâ }\end{array}$ & $\begin{array}{l}\text { Bu çalışmanın amacı, duygusal zekanın ışığında bilişim teknolojisi ve } \\
\text { öğrenci duyguları ile fen bilimleri okuryazarlığı arasında anlamlı bir } \\
\text { farklılık olup olmadığının belirlenmesidir. Bu araştırmada betimsel } \\
\text { araştırma modeli kullanılmıştır. Araştırmanın örneklemini } 15 \text { yaşındaki } \\
5895 \text { Türk öğrencisi oluşturmaktadır. Bu araştırmada PISA } 2015 \\
\text { uygulamaları kapsamında toplanmış olan } 15 \text { yaş grubundaki öğrencilere } \\
\text { ait öğrenci anketleri ile fen okuryazarlığı testlerinden elde edilen } \\
\text { verilerden yararlanılacaktır. Bu çalışmada PISA 2015'de yer alan } \\
\text { öğrencilerin kişisel özelliklerin tamamına cevap verenler (Duygusal } \\
\text { Zekası Yüksek) ve cevap vermeyenler (Duygusal Zekası Düşük) olmak } \\
\text { üzere } 2 \text { gruba ayrılmıştır. } 2 \text { grup için de belirlenen bilişim teknolojileri } \\
\text { ile ilgili öğrenci özelliklerinin fen bilimleri okuryazarlığına etkisi } \\
\text { belirlenmiştir. Duygusal Zekası yüksek bireylerin fen bilimleri } \\
\text { okuryazarlığının daha fazla olduğu sonucuna ulaşılmıştır. Öğrencilerin } \\
\text { duyguları, evde bilişim teknolojisine sahip olması ve bunların niceliksel } \\
\text { olarak artışı fen bilimleri okuryazarlığını olumlu etkilediği sonucuna } \\
\text { ulaşılmıştır. }\end{array}$ \\
\hline
\end{tabular}




\section{Journal of Computer and Education Research}

(ISSN:2148-2896)

December 2017 Volume 5 Issue 10

www.joucer.com

http://dergipark.gov.tr/jcer

Summary

\section{Determination of the Relationship Between Information Technology, Student Emotions and Science Literacy in the Light of Emotional Intelligence}

\section{Introduction}

The applications of Science-Technology-Engineering-Mathematics (STEM) which started to be used in recent years. Two of these four concepts are science and technology, and the relationship between these concepts is tried to be conveyed to the daily life and the curriculum. From this respect, the curriculum developers and educators should be supported through researches carried out both at national and international levels. In this study, it is aimed to determine the relationship between technology and Science Literacy of 15 years old students in Turkey by using PISA 2015 data.

\section{Methodology}

In this study, descriptive research model was used. Moreover, it is aimed to determine the relationship between student characteristics related to information technology, the emotions of students and science literacy. As a research instrument, the researcher used the results of cognitive tests utilised by PISA in 2015 to assess students' science literacy skills. In this study, Turkish students are divided into 2 groups. One of these groups who respond all questions about student characteristics (High Emotional Intelligence) and another who does not respond all questions about them (Low Emotional Intelligence).

\section{Findings}

The results of the analysis show that there is a meaningful difference in terms of Science Literacy averages and a link to the internet, computer and educational software that The Turkish students have these at home. Moreover, statistically meaningful relationship was also found between students' science literacy and the number of computers, cell phones with internet access, tablet computers and e-book readers in their home. 


\section{Conclusion}

According to the results of this study, there is a meaningful relationship between science literacy and student's characteristics related to information technology. The results show that the emotions of the students, the information technology that students have at home and the increase the number of this technology positively affect higher science literacy. Furthermore, it was found that the Turkish students with higher emotional intelligence have a higher science literacy. 


\section{Giriș}

Muasır medeniyet hedefine ulaşma konusunda umut verici ve önemli bir adım atmak için ülkemiz adına teknolojinin eğitime katkısını araştırmanın yanında gelecekte eğitimin teknolojiye etkisini de araştırmalıyız. Muasır medeniyetler seviyesine ulaşmak ve bunu korumak için toplumumuzun ve diğer toplumların taleplerini karşılayacak teknolojileri üreten ve geliştiren, gelecekteki nesillerin taleplerini şimdiden öngörerek geleceğin teknolojilerin alt yapısını oluşturup, araştırma ve geliştirme faaliyetlerini gerçekleştirmek için nesillerimizi genelde okuryazar, özel de ise fen bilimleri okuryazarı olarak yetiştirmenin her geçen gün önemi artmaktadır (Kaya ve Doğan, 2016). Diğer taraftan fen bilimleri okuryazarlığının niteliğinin arttırılması için de duygusal zekaya yani duyguların kontrolü ve yönetimi de gereklidir. Çünkü bireylerin var olan kendi potansiyellerinin ortaya çıkarılması için duygusal zekaya ihtiyaç olduğu da vurgulanmaktadır (Cooper ve Sawaf, 1997: Akt. Titrek, 2016).

$\mathrm{Bu}$ çalışmada duygusal zekanın ışığında teknolojinin fen bilimleri okuryazarlığına etkisini ortaya konmadan önce PISA, fen bilimleri okuryazarlığı, duygusal zekâ ve teknoloji ile ilgili kavramlarının genel çerçevesini ortaya koymamız konunun öneminin kavranması açısından önem taşımaktadır.

\section{PISA ve Fen Bilimleri Okuryazarlı̆̆ının Önemi}

Ekonomik İşbirliği ve Kalkınma Örgütü (OECD) tarafından uygulanan PISA, 15 yaş grubundaki öğrencilere üç yılda bir uygulanmaktadır (Polat, Gödek ve Kaya, 2017). Kaya'ya (2017) göre PISA'da vurgu yapılan kavramlardan biri de fen okuryazarlığıdır ve aslında bu kavram ülkemizdeki fen eğitimcileri içine de önemli bir kavramdır. Bunun nedeni, 2006 yılında yenilenen Fen ve Teknoloji Öğretim Programı ile 2013 yılından sonraki Fen Bilimleri Dersi Öğretim Programının vizyonu olarak bu kavramın ön plana çıkmasıdır. Kısaca, ülkemizde uygulanan son 10 yıldaki Fen eğitimi programlarına bakıldığında temel vizyonun fen bilimleri okuryazarı bireyler yetiştirmek olduğu sonucuna ulaşılmaktadır (Kaya ve Doğan, 2017). Bu nedenle fen programlarının öğrenci üzerinde istenilen etkiyi gerçekleştirme konusunda geribildirim alınması için PISA gibi uluslararası projelerle elde edilen çıtılar önemlidir. Bu projeler sayesinde ülkeler eğitimde benimsedikleri amaçların ne kadarını gerçekleştirildiği konusunda değerlendirme yapma imkânı bulmaktadır. 


\section{Duygusal Zeka ve Akademik Başarı Arasındaki İlişki}

Günümüzde duygusal zekanın bilişsel zekaya etkisinin ortaya çıkarılması konusunda yapılan araştırmalara alan yazında daha fazla yer verildiği görülmektedir. Ancak, ilk olarak duygusal zeka, 1990 yılında Mayer ve Salovey tarafından ortaya konulmuştur (Yılmaz Karabulutlu, Yılmaz ve Yurttaş, 2011). Duygusal zeka sayesinde var olan bir probleme yönelik çözüm önerisi üretilmesine ve davranışların kontrolüne, bireylerin kendisinin ve diğer insanların duygularını tanımasına ve bu doğrultuda kendi duygularını kullanmasına olanak sağlanır (Salovey ve Mayer, 1990). Duygusal zeka sayesinde bireyler, özellikle olumsuz koşullar altında empati kurabilme, azimli olma, bulunduğu çevreye uyum gösterebilme, bireysel-kontrol, kendi kendini motive edebilme ve duygularını kontrol edebilme gibi yetenekleri sayesinde ayakta kalmasına ve yaşamını sürdürmesine yardımcı olmaktadır (Yelkikalan, 2006). Örneğin, bir fen sınavında yer alan bütün soruları istenilen zaman içerisinde doğru bir şekilde anlaması ve cevaplandırması için kendisini sınava odaklaması, gerekli olan akıl yürütmeleri kronolojik bir sırada gerçekleştirmesi için motive olması, varsa matematiksel hesaplamaları doğru yapmak için sorumluluk alarak dikkatlice ve özenle yapması aslında öğrencinin akademik başarı için attı̆̆ı adımın duygusal zeka ile ilişkisini göstermektedir. Bu nedenle de duygusal zekanın gelişimi, özellikle bir yanda bilişsel diğer yanda da biyolojik olgunlaşma gibi gelişim süreçleriyle iç içe ve okuldaki başarı da büyük ölçüde -akademik zeka kadar- duygusal zeka da etkilemektedir (Yeşilyaprak, 2001). Bu nedenle duyguların öğrencilerin öğrenmesi ve başarısı üzerinde etkisinden söz edilmektedir (Villavicencio ve Bernardo, 2013). Ayrıca, duygusal zekanın akademik başarıdaki etkisi araştırmalar tarafından da ortaya konmuştur. Bu etkinin pozitif yönde olduğu belirlenen çalışmalar (Mohzan, Hassan, Halil, 2013; Ogundokun ve Adeyemo, 2010; Roy, Sinha ve Suman, 2013; Üzel ve Hangül, 2012; Yahaya, Bachok, Yahaya, Boon, Hashim ve Lee, 2012; Yüksek ve Geban, 2014) ile negatif yönde olan çalışmalar da (Arlı, Altunay ve Yalçınkaya, 2011) vardır. Özetle bilişsel boyutun yanında duygusal boyutta öğrencilerin davranışlarını etkilemektedir (Han ve Johnson, 2012). Ancak akademik başarıların arkasında güçlü duygular vardır ve akademik başarının ön şartlarından biri de bireyin kendisini ve duygularını geliştirmesidir. Bireylerin gelişimlerini nitelikli olarak sağlayabilmesi için süreç içerisinde karşılaştı̆̆ başarısızlıklarda umutsuzluğa kapılmadan, kendine olan güvenini kaybetmeden çalışmaya devam etmesi yani olumsuz düşüncelerin üstesinden gelmesi güçlü duygulara ve duygusal zekaya sahip olmasıyla gerçekleşecektir. 


\section{Teknolojinin Fen Ĕ̆itimindeki Yeri}

Gelecek yüzyılımızı etkileyecek olan 4. Endüstri devrimi sayesinde insan gücüne gerek duyulmaksızın internet ve bilgisayar teknolojilerinin entegrasyonu ile fabrikalar kendi kendine yetecek şekilde dizayn edilecektir. 4. Endüstri Devrimi ile üretim sürecinde ana bileşenleri olarak özellikle yeni nesil donanım, yazılımlar ve cihaz tabanlı internet öne çıııor (Ege, 2014). Program geliştirici olan eğitim uzmanları ve akademisyenler ile uygulayıcıları olan öğretmenlerin gözüyle bu devirde devrim olacak adımlardan birini fen eğitimi alanında atarak gerçekleştirileceğidir. Çünkü, ülkemizin gelişmiş ülkeler ile rekabetinde fen eğitiminin etkisi oldukça önemlidir (Kaya, Polat ve Kaya, 2014). Bu etkinin yansımaları hem Fen ve Teknoloji Programı́nın hem de Fen Bilimleri Dersi Öğretim Programının vizyonu ortak noktasında fen bilimleri okuryazarlığına yer verilmesiyle anlaşılmaktadır (Polat, Gödek ve Kaya, 2016). Fen bilimleri okuryazarlığı sayesinde de doğa örtüsü içinde meraklı ve duyarlı kişileri yetiştirmek amaçlanmıştır (Kaya ve Kazancı, 2009). Bu amaçla Gödek Altuk, Kaya ve Bahçeci'ye (2015) göre ülkemizde de son yıllarda özellikle fen eğitim sisteminde yeniden yapılanmaya gidilmiştir. İleriki yaşamında gerçek anlamıyla fen bilimleri okuryazar olması beklenen bireyin ne kadar erken çağlarda bilime karşı ilgisi ve farkındalı̆̆ geliştirilirse o kadar nitelikli bir fen bilimleri okuryazarı olacağı gerçeği göz ardı edilemez. Bu sayede 4. Endüstri devrimi için atılan önemli adımlardan biri atılabilir. Ancak, 4. Endüstri devriminde başarılı olmak için fen eğitimi sistemimizde gelişigüzel adımlardan uzak durulmalı ve amaca uygun reformlar yapılmalıdır. Bu kapsamda son zamanlarda ön plana çıkan STEM eğitimi akıllara gelmektedir. STEM kısaltması İngilizce olarak Science- Techonology- Engineer and Math kelimelerin baş harflerinin kısalmasıyla oluşturulmuştur (Akgündüz ve Ertepınar, 2015). Türkçemizdeki çevirisi ise Fen- Teknoloji- Mühendislik ve Matematiktir (MEB, 2016b; Şahin, Ayar ve Adıgüzel, 2014). Bu dört kavramın birbirleriyle olan ilişkisinin müfredata aktarılarak bireylerin üretkenliğinin arttırılması hedeflenmektedir. STEM odaklı fen eğitiminin sistemli bir şekilde programa dahil edilmesi ve öğrencilerde istenilen davranış değişikliğine imkan sağlayacak şekilde uygulanması gereklidir. Elbette S(İS)TEM(LI), eğitimin niteliğinde ve 4. Endüstri devriminde önemli rol oynayabilir ve (İ)STEMLİ davranış değişikliğine neden olunabilir. Bunun yanında toplum olarak 4. Endüstri devriminin gelecek nesillerle gerçekleşebileceği bilinci oluşturulmalı ve geliştirilmelidir. Gelecek nesillerin sorumluluk almaları özendirilmeli, başarısızlıklarında yanında olunmalı ve bu doğrultuda küçük başarıların peşinden gelecek olan büyük başarılara da ışık tutulmalıdır. Bu konuda hayaller 
kurmalı ve bunları gerçekleştirmelerine imkan sağlanmalıdır. Bu kapsamda atılan adımlardan biri Fatih Projesi'dir. Millî Eğitim Bakanlığı'na (2016a) göre eğitimde Fırsatları Artırma ve Teknolojiyi İyileştirme Hareketi (FATïH) Projesi, eğitim ve öğretimde fırsat eşitliğini sağlamak ve okullarımızdaki teknolojiyi iyileştirmek amacıyla bilişim teknolojileri araçlarının öğrenme-öğretme sürecinde daha fazla duyu organına hitap edilecek şekilde, derslerde etkin kullanımı için başlatılmıştır. Bu kapsamda her öğrencimizin en iyi eğitimi alması, en kaliteli eğitim içeriklerine ulaşması ve eğitimde fırsat eşitliğinin sağlanması için tasarlanmış olan bu proje, eğitimde teknoloji kullanımıyla ilgili dünyada uygulamaya konulan en büyük ve en kapsamlı eğitim hareketidir. Bu eğitim hareketinin niteliğini artırmak için çalışmalar yapılmaktadır. Örneğin, Eğitim Bilişim Ağı (EBA) platformu sayesinde bilgi teknolojileri aracılığıyla etkili materyal kullanımını destekleyip teknolojinin eğitim ile bütünleşmesine olanak tanıyan ve EBA' da bulunan e-içerikler, alanında uzman ekipler tarafından üretilmekte, eğitim ve teknolojideki yenilikleri takip ederek gelişmeye devam etmektedir (EBA, 2016).

Günümüzde teknolojinin fen eğitimine yönelik olumlu ve(ya) olumsuz etkilerinin ortaya çıkarılması ve bu doğrultuda fen programının hedef ve amaçlarının belirlenmesi başarıyı olumlu yönde etkileyecektir. Yapılan araştırmalarla teknolojiyi bulundurma durumu ve(ya) niceliği fen başarısına etkisi olduğu belirtilmektedir (Kaya ve Doğan, 2016; Delen ve Bulut, 2011). Ayrıca teknolojiyi bilinçli kullanma konusunda duyguların öneminin de ortaya çıkarılması gereklidir. $\mathrm{Bu}$ nedenle teknoloji odaklı eğitim materyallerinin ve fen programlarının hızlı bir şekilde yaygınlaşmasının fen bilimleri başarısına etkisini araştırmanın yanında duygusal becerilerinde fen bilimleri başarısındaki etkisi de belirlenmeye çalışılması gereklidir. Elde edilecek sonuçlar, fen bilimleri başarısını artırmak için teknolojinin etkin kullanımına ve duyguların nitelikli gelişimine yönelik çözüm önerileri ortaya koyma imkanı sunacaktır. Bu nedenle bu araştırmanın amacı bilişim teknolojisi ve öğrenci duyguları ile fen bilimleri okuryazarlığı arasında anlamlı bir farklılığın olup olmadığının belirlenmesidir.

Ayrıca, bu çalışmada Türkiye örneklemi kendi içerisinde duygusal zekası yüksek ve düşük olmak üzere 2 gruba ayrılmıştır. Bu gruplama PISA 2015'de yer alan öğrenci özelliklerine ait (sosyo-ekonomik ve kişisel özellikler gibi) anketin tamamına cevap verenler (Duygusal Zekası Yüksek Grup (DZYG)) ve cevap vermeyenler (Duygusal Zekası Düşük Grup (DZDG))'dir. PISA'da duygusal zeka doğrudan ölçülememesine rağmen (Chuan, 2016; Davie, 2013), duygusal zekanın yüksek ve düşük olan bireylerin okuryazarlık puanları dolaylı olarak ortaya konulabilir. Çünkü duygusal zekası yüksek olan bireyler; duygularının 
farkında, duygularını açık bir şekilde ifade edebilen, topluma karşı duyarlı, sorunların çözümünde sorumlu, sabırlı, hoşgörülü, tutarlı, kararlı ve azimli olarak tanımlanmaktadır (Somuncuoğlu, 2005). Dolayısıyla PISA'da kendisi ve ailesi ile ilgili soruların tamamını cevaplandırması için öğrenciler kararlı, azimli ve sabırlı olmalıdır. Öğrenci özellikleri içerisinde yer alan duygularla ilişkili soruların tamamını şeffaf bir şekilde cevaplandırılması da duygularını açık bir şekilde ifade ettiği sonucuna ve bunları doğru bir şekilde cevaplandırmaya çalışması da duygularının farkında olduğunun sonucuna ulaştırabilir. Diğer taraftan öğrencilerin sorulara verdikleri cevaplar doğrultusunda eğitimciler, eğitimde yapılacak yeniliklere yön verecek ve var olan aksaklıkların giderilmesine katk1 sağlayacaklardır. Öğrenciler bu sayede toplumsal sorunların çözümünde sorumluluk aldığ ve topluma karşı duyarlı olduğu da belirtilebilir. Bu nedenle bu çalışma da soruların tamamını cevaplandıranlar ve cevaplandırmayanlar olmak üzere örneklem iki gruba ayrılarak duygusal zekanın 1şığında öğrencilerin fen bilimleri okuryazarlıkları kıyaslanmıştır.

PISA 2015 verilerine göre öğrenci duyguları ile bilişim teknolojileri açısından bu iki grubun fen bilimleri okuryazarlığı ortalamaları belirlenmeye çalışılmıştır. Bu grupların fen bilimleri okuryazarlığı ile bilişim teknolojileri ve öğrencilerin duyguları arasında anlamlı farklılık olup olmadığı belirlenmeye çalışılmıştır.

1. Öğrenci özelliklerine ait anketin tamamını cevaplandıranların ve cevaplandırmayanların (duygusal zekası yüksek ve düşük olanların) fen bilimleri okuryazarlığı ortalaması nedir?

2. Duygusal zekası yüksek ve düşük olan grupların sınav kaygısı ve motivasyon duygularının ortalaması nedir?

3. Bilişim Teknolojilerini evinde bulundurma durumu (bilgisayar, internet ve eğitim yazılımı) ve sayısı (internet bağlantılı telefon, bilgisayar, tablet ve e-kitap okuyucusu) ile duygusal zekası yüksek ve düşük olan grupların fen bilimleri okuryazarlığı arasında anlamlı bir farklılık var mıdır?

4. Öğrencinin eğitim düzeyi hedefleri ile duygusal zekası yüksek ve düşük olan gruplardaki fen bilimleri okuryazarlığı arasında anlamlı bir farklılık var mıdır?

\section{Yöntem}

Bu bölümde araştırmanın yöntemi, evren ve örneklem, veri toplama araçları, verilerin toplanması ve analizi hakkında bilgilere ayrıntılı olarak yer verilmiştir. 


\section{Araştırmanın Modeli}

$\mathrm{Bu}$ araştırmada en çok tercih edilen araştırma yaklaşımlarından biri olan nicel araştırma yaklaşımlarından biri olan betimsel model benimsenmiştir (Selçuk, Palancı, Kandemir ve Dündar, 2014). Betimsel analiz sayesinde veriler düzenli bir şekilde sunulması ve “Ne?" sorusuna cevap bulma imkanı vermektedir (Eryılmaz Toksoy ve Akdeniz, 2015). Bu model sayesinde araştırmayı özetleme ve yorumlama imkanı olmaktadır (Yıldırım ve Şimşek, 2003). Araştırma deseni olarak geniş örneklem ile çalışma imkanı sunan tarama yöntemi kullanılmıştır. Tarama (survey) yöntemi ile geniş kitlelerin görüşlerini ve durumlarını tanımlamayı amaçlayan araştırmalardır (Büyüköztürk vd., 2008).

\section{Araştırma Örneklemi}

Bu araştırmada PISA 2015 uygulamasına katılan 15 yaş grubundaki Türk öğrencilere ait öğrenci anketlerden ve fen okuryazarlığı testlerinden elde edilen verilerden yararlanılmıştır. Türkiye örnekleminde yer alan 5895 öğrencilerinden 938'si kız, 2957'si erkektir. PISA 2015 verilerine göre fen bilimleri okuryazarlığı ortalaması 425 iken; OECD ortalaması 493' dür (OECD, 2016).

\section{Verilerin Toplanması}

Bu çalışmada veri toplama aracı olarak PISA 2015'de 15 yaş grubu öğrencilerin fen okuryazarlığına ilişkin becerilerini ölçmeye yönelik bilişsel testler kullanılmıştır. Araştırmanın bağımlı değişkeni olan fen bilimleri okuryazarlığı ortalaması hesaplanırken, bilişsel alana ait fen bilimleri okuryazarlığı puanlarının (PV1SCIE ile PV10SCIE arasındaki) ortalaması alınarak hesaplanmıştır. Ayrıca bağımsız değişkenler belirlenirken, öğrencilerin bilişim teknolojileri ve duyguları ile ilgili özelliklerine ait cevaplardan yararlanılmıştır. Bu çalışmada kullanılan bilişim teknolojileri ve öğrenci duyguları ile ilgili öğrenci özelliklerine ve bilişsel testlere ait envanterler OECD PISA'nın resmi sitesindeki (http://www.pisa.oecd.org) veri dosyalarından internet aracılığı ile elde edilmiştir.

\section{Verilerin Analizi}

$\mathrm{Bu}$ araştırmada veriler OECD'nın web sitesinden temin edildikten sonra veri analizi SPSS 20 programı ile yapılmıştır. PISA 2015 verilerinde yer alan bilişsel testler sonucunda elde edilen fen bilimleri okuryazarlıkları puanlarının ortalaması hesaplanmıştır. Öğrencinin kişisel testlere verdikleri cevaplardan bilişim teknolojileri ve öğrenci duyguları ile ilişkili niceliksel özellikler seçilmiştir. Araştırma kapsamında verileri analiz edebilmek için araştırmada fen bilimleri okuryazarlığı (bağımlı değişken) ile diğer değişkenler (özellikle teknoloji ile ilgili 
özellikler) arasında anlamlı bir farklılık olup olmadığı belirlenmeye çalışılmış ve sınanmıştır. Ayrıca örneklem iki gruba ayrılarak (duygusal zekası yüksek ve düşük) bu iki grup arasındaki ortalama puanlar karşılaştırılmıştır.

$\mathrm{Bu}$ araştırmanın analiz türünü belirlerken, araştırmanın nicel verilerinin analizinden elde edilen verilerin değerlendirilmesinde parametrik testler ( $t$ testi) uygulanmasına karar verilmiştir. Çünkü, literatür taraması sonucunda grup büyüklüğü 20 ve üzerinde olduğunda verilerin normal dağıldığı varsayılabileceğini ifade etmektedir (Tabachnick ve Fidell, 2001). Çıkarımsal fark istatistikleri yani t-testi ve ANOVA'dan yararlanılarak gruplar arası farkı ortaya koymak isteyen araştırma yaklaşımı kullanılmıştır (Gliner, Morgan ve Leech, 2015). Parametrik testlerden biri olan t-testi ile iki örneklemin ortalamalarının eşit olup olmadığ hipotezini test edilirken; bir diğeri ANOVA ile de üç ya da daha fazla ortalamanın eşit olup olmadığını test edilir. Bu nedenle bu çalışmada t-testleri ve ANOVA'dan yararlanılmıştır. ANOVA çalışmasında Scheffe testinden yararlanılmıştır. Bunun nedeni Scheffe çoklu karşılatırma test istatistiğinin, bilimsel dayanağı sağlam olabilecek post-hoc test türünden birisi olduğu için tercih edilmiştir (Kayri, 2009).

\section{Bulgular}

İlk defa PISA 2015'de veriler ülkemiz için bilgisayar tabanlı değerlendirme şeklinde gerçekleşmiştir. Tablo 1'de Öğrencilerin PISA 2015 öğrenci özelliklerine ait anketin cevaplandırması ile Fen Bilimleri Okuryazarlığı durumu arasında ilişkisi yer almaktadır.

Tablo 1: Öğrencilerin PISA 2015 Öğrenci Özelliklerine ait Anketin Cevaplandırmasının Fen Bilimleri Okuryazarlığı Durumuna Göre T-Testi Sonuçları

\begin{tabular}{ccccccccc}
\hline & $\begin{array}{c}\text { Öğgenci anketin } \\
\text { tamamının } \\
\text { cevaplandırılma durumu }\end{array}$ & $\mathrm{N}$ & $\bar{X}$ & $\mathrm{~S}$ & $\mathrm{Sd}$ & $\mathrm{t}$ & $\mathrm{p}$ \\
\hline PISA & Evet (DZYG) & 2375 & 446,82 & 69,96 & 5893 & 22,36 & \\
$\mathbf{2 0 1 5}$ & Hayır (DZDG) & 3520 & 405,10 & 70,50 & & &, 00 \\
\hline $\mathrm{p}<0,01$ & & & & & & &
\end{tabular}

Analiz sonuçları, Türk öğrencilerin fen bilimleri okuryazarlığı ortalamasının PISA 2015 öğrenci özelliklerine ait anketin tamamının cevaplandırma durumuna göre anlamlı bir farklılık göstermektedir, $\mathrm{t}(5893)=22,36, \mathrm{p}<0.01$. Anketin tamamın bilgisayar ortamında cevaplayan öğrencilerin fen bilimleri okuryazarlığı ortalamaları (X= 446,82), cevaplandırmayana $(X=405,10)$ göre daha olumludur.Öğrencinin kendi özellikleri ile ilgili soruların tamamının cevaplandırması için azim göstermesi, bireysel sorumluluk alması ve 
motivasyonunu sağlaması onların cevaplandırmayanlara göre daha yüksek duygusal zekaya sahip olduğu ifade edilebilir.

Duygusal zekası yüksek ve düşük olan grupların öğrencilerin kişsel sınav endişesi ve motivasyonu ile özelliklerin benzerlik ve farklılıkları gözlemleyebilmek için PISA 2015 verilerine göre tablo 2'de öğrencilerin kişisel sınav endişesi ve motivasyon ile ilgili istatistiki sonuçlar yer almaktadır.

Tablo 2. Öğrencilerin Kişisel Sınav Endişesi ve Motivasyon ile İlgili İstatistiki Sonuçlar

\begin{tabular}{ccccccc}
\hline & & $\mathrm{N}$ & $X$ & $\mathrm{~S}$ & Min & Max \\
& & & & & & \\
\hline Kişisel Sinav & DZYG & 2375 & 0,34 & 1,04 & $-2,51$ & 2,55 \\
Endişesi & DZDG & 3520 & 0,31 & 1,07 & $-2,51$ & 2,55 \\
\hline Motivasyon & DZYG & 2375 & 0,68 & 0,98 & $-3,09$ & 1,85 \\
& DZDG & 3520 & 0,57 & 1,07 & $-3,09$ & 1,85 \\
\hline
\end{tabular}

Tablo 2'de görüldüğü üzere öğrenci anketinin tamamını cevaplandıran öğrencilerin (DZYG) kişisel sınav endişesi ve motivasyonu, cevaplandırmayanlara (DZDG) göre daha yüksek ortalamaya sahip olduğu sonucuna ulaşılmıştır. Bu nedenle duygusal zekası yüksek olan öğrencilerin motivasyonları ve sınav kaygılarının yüksek olduğu sonucuna ulaşılmıştır.

Tablo 3'de evinde okul ödevleri için kullanılabilecek bilgisayar bulundurma durumunun duygusal zekası yüksek olan grup (DZYG) ile duygusal zekası düşük olan grubun (DZDG) fen bilimleri okuryazarlığı arasındaki anlamlı bir farklılığın olup olmadığına yönelik bulgular yer almaktadır.

Tablo 3.Öğrencilerin Fen Bilimleri Okuryazarlığı Ortalamasının evinde okul ödevleri için kullanılabilecek bilgisayar bulundurma Durumuna Göre T-Testi Sonuçları

\begin{tabular}{cccccccc}
\hline & $\begin{array}{c}\text { Bilgisayar Bulunma } \\
\text { Durumu }\end{array}$ & $\mathrm{N}$ & $X$ & $\mathrm{~S}$ & $\mathrm{Sd}$ & $\mathrm{t}$ & $\mathrm{p}$ \\
\hline \multirow{2}{*}{ DZYG } & Evet & 1746 & 455,41 & 68,77 & 2373 & 10,18 &, 00 \\
& Hayır & 629 & 422,99 & 67,72 & & & \\
\hline \multirow{2}{*}{ DZDG } & Evet & 2136 & 421,11 & 71,40 & 3385 & 16,21 &, 00 \\
& Hayır & 1251 & 381,88 & 61,63 & & & \\
\hline
\end{tabular}

$\mathrm{p}<0,01$

Analiz sonuçlarına göre duygusal zekası yüksek ve düşük olan grupların fen bilimleri okuryazarlığı ortalamasının evinde okul ödevleri için kullanılabilecek bilgisayar bulundurma durumuna göre anlamlı bir farklılık göstermektedir, t (2373) $)_{D Z Y G}=10,18, t$ (3385) $)_{\text {ZDDG }}=16,21$. Duygusal zekası yüksek olan grupta ev ödevleri için bilgisayar bulundurulanların fen bilimleri okuryazarlığı ortalamaları $(X=455,41)$, bulundurmayanlara $(X=422,99)$ göre daha olumludur. Duygusal zekası düşük olan grupta ev ödevleri için bilgisayar bulundurulanların 
fen bilimleri okuryazarlığı ortalamaları $(X=421,11)$, bulundurmayanlara $(X=381,88)$ göre daha olumludur. Burada dikkat çekici bulgulardan biri de duygusal zekası yüksek olan grupta ev ödevleri için bilgisayar bulundurmayanların fen bilimleri okuryazarlığı ortalamaları $(X=$ 422,99), duygusal zekası düşük olan grupta ev ödevleri için bilgisayar bulunduranlara (X= 421,11) göre daha olumludur.

Tablo 4'de evinde internet bağlantısının bulunma durumunun DZYG ile DZDG'un fen bilimleri okuryazarlığı arasında anlamlı bir farklılığın olup olmadığına yönelik bulgular yer almaktadır.

Tablo 4.Öğrencilerin Fen Bilimleri Okuryazarlığı Ortalamasının Evinde İnternet Bağlantısının Bulunma Durumuna Göre t-Testi Sonuçları

\begin{tabular}{cccccccc}
\hline & $\begin{array}{c}\text { Internet Bulunma } \\
\text { Durumu }\end{array}$ & $\mathrm{N}$ & $\bar{X}$ & $\mathrm{~S}$ & $\mathrm{Sd}$ & $\mathrm{t}$ & $\mathrm{p}$ \\
\hline \multirow{2}{*}{ DZYG } & Evet & 1606 & 456,66 & 68,52 & 2373 & 10,11 & \multirow{2}{*}{00} \\
& Hayır & 769 & 426,28 & 68,48 & & & \\
\hline \multirow{2}{*}{ DZDG } & Evet & 2029 & 421,69 & 71,72 & 3385 & 15,88 & \multirow{2}{*}{00} \\
& Hayır & 1368 & 383,81 & 62,54 & & & \\
\hline
\end{tabular}

$\mathrm{p}<0,01$

Analiz sonuçlarına göre duygusal zekası yüksek ve düşük olan grupların fen bilimleri okuryazarlığı ortalamasının evinde internet bağlantısının bulunma durumuna göre anlamlı bir farklılık göstermektedir, t (2373) DZYG $=10,11$, t (3385) DZDG $=15,88$. Duygusal zekası yüksek olan grupta internet bağlantısı bulundurulanların fen bilimleri okuryazarlığı ortalamaları $(X=$ $456,66)$, bulundurmayanlara $(X=426,28)$ göre daha olumludur. Duygusal zekası düşük olan grupta da internet bağlantısı bulundurulanların fen bilimleri okuryazarlığı ortalamaları $(X=$ 421,69), bulundurmayanlara $(X=383,81)$ göre daha olumludur. Burada dikkat çekici sonuçlardan birisi tıpkı bilgisayar bulundurma durumunda olduğu duygusal zekası yüksek olan grupta internet bağlantısı bulundurmayanların fen bilimleri okuryazarlığı ortalamaları ( $X=456,66)$, duygusal zekası düşük olan grupta ev ödevleri için internet bağlantısı bulunduranlara $(X=421,69)$ göre daha olumludur. Aslında internet bağlantısı bulundurma fen bilimleri okuryazarlığını arttırsa da duygusal zekası gelişmiş olan bireyler, sınırsız ve her geçen gün bilginin arttığı ortama ulaşıma imkan sağlayan interneti kendi amaçları doğrultusunda bilinçli kullanması daha önemlidir.

Tablo 5'te evinde eğitim yazılımı bulunma durumunun DZYG ile DZDG'un fen bilimleri okuryazarlığı arasında anlamlı bir farklılığın olup olmadığına yönelik bulgular yer almaktadir. 
Tablo 5.Öğrencilerin Fen Bilimleri Okuryazarlı̆̆ı Ortalamasının Evinde Eğitim Yazılımı Bulunma Durumuna Göre T-Testi Sonuçları

\begin{tabular}{cccccccc}
\hline & $\begin{array}{c}\text { Eğitim Yazılımı } \\
\text { Bulunma Durumu }\end{array}$ & $\mathrm{N}$ & $\mathrm{X}$ & $\mathrm{S}$ & $\mathrm{Sd}$ & $\mathrm{t}$ & $\mathrm{p}$ \\
\hline \multirow{2}{*}{ DZYG } & Evet & 978 & 451,54 & 71,10 & 2373 & 2,75 & \multirow{2}{*}{006} \\
& Hayır & 1397 & 443,52 & 68,98 & & & \\
\hline \multirow{2}{*}{ DZDG } & Evet & 1366 & 406,68 & 72,65 & 3385 & 0,35 & \multirow{2}{*}{, 73} \\
& Hayır & 1847 & 407,56 & 69,23 & & & \\
\hline
\end{tabular}

$\mathrm{p}<0,01$

Analiz sonuçlarına göre duygusal zekası yüksek olan grubun fen bilimleri okuryazarlığı ortalamasının evinde eğitim yazılımı bulunma durumuna göre anlamlı bir farklılık gösterirken, duygusal zekası düşük olan grubun ise anlamlı bir farklılık yoktur, $\mathrm{t}$ $(2373)_{\text {DZYG }}=2,75, \mathrm{p}<0.01 ; \mathrm{t}(3385) \mathrm{DZDG}=0,35$. Duygusal zekas1 yüksek olan grupta eğitim yazılımı bulundurulanların fen bilimleri okuryazarlığı ortalamaları $(X=451,54)$, bulundurmayanlara $(X=443,52)$ göre daha olumludur. Duygusal zekası düşük olan grupta da eğitim yazılımı bulundurulanların fen bilimleri okuryazarlığı ortalamaları $(X=406,68)$, ile bulundurmayanlar $(X=407,56)$ hemen hemen aynıdır.

Tablo 6'da evinde internet bağlantılı telefon sayısına göre DZYG ile DZDG'un fen bilimleri okuryazarlığı arasındaanlamlı bir farklılığın olup olmadığına yönelik bulgular yer almaktadir.

Tablo 6.Öğrencilerin Fen Bilimleri Okuryazarlığı Ortalamasının Internet Bağlantılı Telefon Sayısına Göre ANOVA Sonuçları

\begin{tabular}{|c|c|c|c|c|c|c|c|c|c|}
\hline & $\begin{array}{c}\text { Telefon } \\
\text { Sayısı }\end{array}$ & $\mathrm{N}$ & $X$ & $\begin{array}{c}\text { Varyansın } \\
\text { kaynağ1 }\end{array}$ & $\mathrm{Sd}$ & $\begin{array}{c}\text { Kareler } \\
\text { Ortalaması }\end{array}$ & $\mathrm{F}$ & $\mathrm{p}$ & Fark \\
\hline \multirow{4}{*}{ DZYG } & Hiç (a) & 162 & 406,86 & Gruplararası & 3 & 197608,69 & \multirow{4}{*}{42,50} & \multirow{4}{*}{, 00} & \multirow{4}{*}{$\begin{array}{c}a-c, a- \\
d, b-c \\
b-d\end{array}$} \\
\hline & $1(b)$ & 457 & 426,45 & Gruplariçi & 2371 & 4649,79 & & & \\
\hline & $2(\mathrm{c})$ & 532 & 454,00 & Toplam & 2374 & & & & \\
\hline & $\begin{array}{c}3 \text { ve } \\
\text { fazlasi }(\mathrm{d})\end{array}$ & 1224 & 456,60 & & & & & & \\
\hline \multirow{4}{*}{ DZDG } & Hiç (a) & 412 & 365,57 & Gruplararası & 3 & 457144,94 & & & \multirow{4}{*}{$\begin{array}{l}a-b, a- \\
c, a-d\end{array}$} \\
\hline & 1(b) & 809 & 388,42 & Gruplariçi & 3413 & 4570,17 & 100,03 & ,00 & \\
\hline & 2(c) & 713 & 415,37 & Toplam & 3416 & & & & \\
\hline & $\begin{array}{c}3 \text { ve } \\
\text { fazlasi (d) }\end{array}$ & 1483 & 422,12 & & & & & & \\
\hline
\end{tabular}

$\mathrm{p}<0,01$

Analiz sonuçları, duygusal zekası yüksek ve düşük olan grubun fen bilimleri okuryazarlığı ortalaması ile internet bağlantılı telefon sayısı açısından anlamlı bir fark olduğunu göstermektedir, FDZYG $(3,2371)=42,50 ; F_{D Z D G}(3,3413)=100,03$. Scheffe testinin sonuçlarına göre duygusal zekası yüksek olan grubun 3 ve daha fazla internet bağlantılı telefona sahip olanların ( $X=456,60), 2$ adet internet bağlantılı telefona sahip olanlara $(X=$ 
454,00), 1 adet internet bağlantılı telefona sahip olanlara $(X=426,45)$ ve hiç sahip olmayanlara göre $(X=406,86)$ göre fen bilimleri okuryazarlık ortalamalarının daha olumlu olduğu belirlenmiştir. Benzer bir durum duygusal zekası düşük olan grupta söz konusudur. Ancak duygusal zekası yüksek ve düşük grupların ortalamaları kıyaslandığında duygusal zekası yüksek olan grubun fen bilimleri okuryazarlığı ortalaması daha fazla olduğu görülmektedir. İnternet bağlantılı telefonun sayısı arttıkça, telefonla etkileşim süresini arttırdığı için bu durumda bilgiye ulaşılmasına imkanı daha fazla olmaktadır. Bu nedenle de fen bilimleri okuryazarlığı artmaktadır.

Tablo 7'de evinde bilgisayar sayısına göre DZYG ile DZDG'un fen bilimleri okuryazarlığı arasında anlamlı bir farklılığın olup olmadığına yönelik bulgular yer almaktadir.

Tablo 7.Öğrencilerin Fen Bilimleri Okuryazarlığı Ortalamasının Bilgisayar Sayısına Göre ANOVA Sonuçları

\begin{tabular}{|c|c|c|c|c|c|c|c|c|c|}
\hline & $\begin{array}{c}\text { Bilgisayar } \\
\text { Sayısı }\end{array}$ & $\mathrm{N}$ & $X$ & $\begin{array}{l}\text { Varyansın } \\
\text { kaynağı }\end{array}$ & Sd & $\begin{array}{c}\text { Kareler } \\
\text { Ortalaması }\end{array}$ & $\mathrm{F}$ & $\mathrm{p}$ & Fark \\
\hline \multirow{4}{*}{ DZYG } & Hiç (a) & 534 & 422,52 & Gruplararası & 3 & 195372,11 & \multirow{4}{*}{41,99} & \multirow{4}{*}{,00 } & \multirow{4}{*}{$\begin{array}{c}a- \\
b, a- \\
c, a-d\end{array}$} \\
\hline & 1(b) & 1217 & 446,80 & Gruplariçi & 2371 & 4652,62 & & & \\
\hline & $2(\mathrm{c})$ & 463 & 467,91 & Toplam & 2374 & & & & \\
\hline & 3 ve fazlası (d) & 161 & 466,90 & & & & & & \\
\hline \multirow{4}{*}{ DZDG } & $\operatorname{Hiç~(a)~}$ & 1126 & 378,68 & Gruplararası & 3 & 532879,41 & \multirow{4}{*}{118,73} & \multirow{4}{*}{,00 } & \multirow{4}{*}{$\begin{array}{c}a- \\
b, a- \\
c, a-d\end{array}$} \\
\hline & $1(\mathrm{~b})$ & 1582 & 412,42 & Gruplariçi & 3414 & 4488,24 & & & \\
\hline & $2(\mathrm{c})$ & 528 & 431,92 & Toplam & 3417 & & & & \\
\hline & 3 ve fazlası (d) & 182 & 449,14 & & & & & & \\
\hline
\end{tabular}

Analiz sonuçları, duygusal zekası yüksek ve düşük olan grubun fen bilimleri okuryazarlığı ortalaması ile bilgisayar sayısı açısından anlamlı bir fark olduğunu göstermektedir, $F_{D Z Y G}(3,2371)=41,90 ; F_{D Z D G}(3,3414)=118,73$. Scheffe testinin sonuçlarına göre, duygusal zekası yüksek olan grupta 3 ve daha fazla bilgisayara sahip olanların ( $X=466,90)$ ve 2 adet bilgisayara sahip olanların $(X=467,91), 1$ adet bilgisayara sahip olanlara $(X=446,80)$ ve hiç sahip olmayanlara göre $(X=422,52)$ göre fen bilimleri okuryazarlık ortalamalarının daha olumlu olduğu belirlenmiştir. Benzer bir durum duygusal zekası düşük olan grupta da söz konusudur. Ancak duygusal zekası yüksek ve düşük grupların ortalamaları kıyaslandığında, duygusal zekası yüksek olan grubun fen bilimleri okuryazarlığı ortalaması daha fazla olduğu görülmektedir. İnternet bağlantılı telefonun sayısında olduğu gibi bilgisayar sayısı arttıkça da tabletle etkileşim süresini arttırdığı için bu durumda daha fazla bilgiye ulaşılmasına imkan sağlamakta bu nedenle fen bilimleri okuryazarlığı artmaktadır. 
Tablo 8'de evinde tablet bilgisayar sayısına göre DZYG ile DZDG'un fen bilimleri okuryazarlığı arasında anlamlı bir farklılığın olup olmadığına yönelik bulgular yer almaktadır.

Tablo 8.Öğrencilerin Fen Bilimleri Okuryazarlığı Ortalamasının Tablet Bilgisayar Sayısına Göre ANOVA Sonuçları

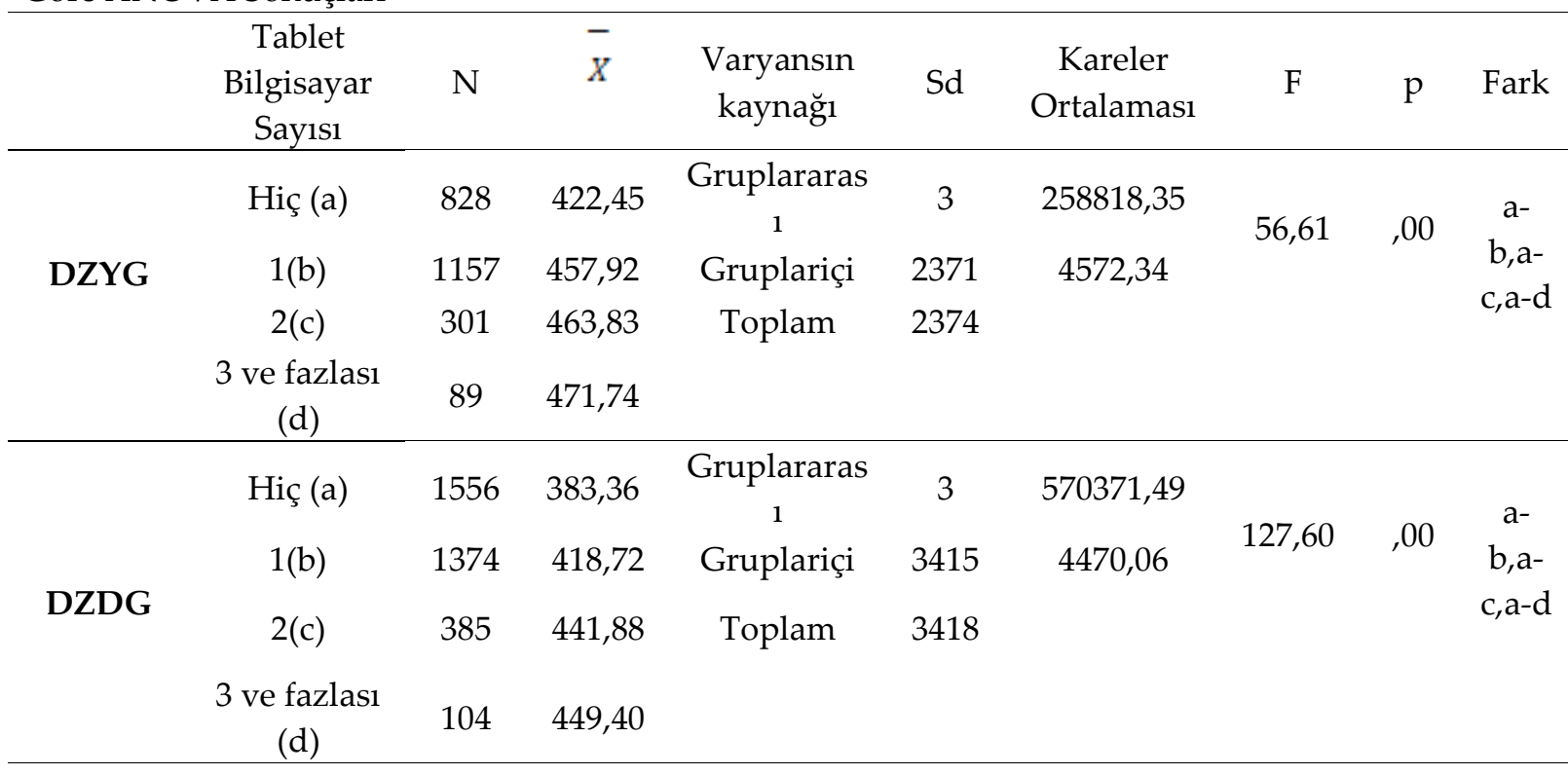

Analiz sonuçları, duygusal zekası yüksek ve düşük olan grubun fen bilimleri okuryazarlığı ortalaması ile tablet bilgisayar sayısı açısından anlamlı bir fark olduğunu

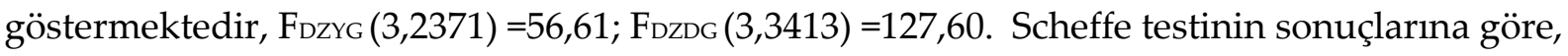
duygusal zekası yüksek olan grupta 3 ve daha fazla tablet bilgisayara sahip olanların ( $\mathrm{X}=$ 471,74), 2 adet tablet bilgisayara sahip olanlara $(X=463,83), 1$ adet tablet bilgisayara sahip olanlara $(X=457,92)$ ve hiç sahip olmayanlara göre $(X=422,45)$ göre fen bilimleri okuryazarlık ortalamalarının daha olumlu olduğu belirlenmiştir. Benzer bir durum duygusal zekası düşük olan grupta da söz konusudur. Ancak duygusal zekası yüksek ve düşük grupların ortalamaları kıyaslandığında duygusal zekası yüksek olan grubun fen bilimleri okuryazarlığı ortalaması daha fazla olduğu görülmektedir. İnternet bağlantılı telefon ve bilgisayar sayısında olduğu gibi tablet sayısı arttıkça da tabletle etkileşim süresini arttırdığı için bu durumda daha fazla bilgiye ulaşılmasına imkan sağlamaktadır, bu nedenle fen bilimleri okuryazarlığı artmaktadir.

Tablo 9'de evinde e-kitap okuyucu sayısına göre DZYG ile DZDG'un fen bilimleri okuryazarlığı arasında anlamlı bir farklılığın olup olmadığına yönelik bulgular yer almaktadır. 
Tablo 9. Öğrencilerin Fen Bilimleri Okuryazarlığı Ortalamasının E-kitap Okuyucu Sayısına Göre ANOVA Sonuçları

\begin{tabular}{|c|c|c|c|c|c|c|c|c|c|}
\hline & $\begin{array}{c}\text { E-kitap } \\
\text { Okuyucu } \\
\text { Sayısı }\end{array}$ & $\mathrm{N}$ & $\bar{X}$ & $\begin{array}{l}\text { Varyansın } \\
\text { kaynağ1 }\end{array}$ & $\mathrm{Sd}$ & $\begin{array}{l}\text { Kareler } \\
\text { Ortalaması }\end{array}$ & $\mathrm{F}$ & $\mathrm{p}$ & $\begin{array}{c}\text { Far } \\
k\end{array}$ \\
\hline \multirow{4}{*}{ DZYG } & Hiç (a) & 2257 & 447,74 & $\begin{array}{c}\text { Gruplararas } \\
1\end{array}$ & 3 & 16099,86 & \multirow{4}{*}{3,30} & \multirow{4}{*}{,02 } & \multirow{4}{*}{-} \\
\hline & 1(b) & 95 & 433,70 & Gruplariçi & 2371 & 4879,45 & & & \\
\hline & 2(c) & 8 & 402,58 & Toplam & 2374 & & & & \\
\hline & $\begin{array}{c}3 \text { ve fazlası } \\
\text { (d) }\end{array}$ & 15 & 415,84 & & & & & & \\
\hline \multirow{4}{*}{ DZDG } & Hiç (a) & 3120 & 407,64 & $\begin{array}{c}\text { Gruplararas } \\
1\end{array}$ & 3 & 26299,37 & \multirow{4}{*}{5,32} & \multirow{4}{*}{,00 } & \multirow{4}{*}{$d-a$} \\
\hline & 1(b) & 162 & 400,84 & Gruplariçi & 3347 & 4942,36 & & & \\
\hline & 2(c) & 42 & 381,01 & Toplam & 3350 & & & & \\
\hline & $\begin{array}{c}3 \text { ve fazlasi } \\
\text { (d) }\end{array}$ & 27 & 366,87 & & & & & & \\
\hline
\end{tabular}

Analiz sonuçları, duygusal zekası düşük olan grubun fen bilimleri okuryazarlığı ortalaması ile e-kitap okuyucu sayısı açısından anlamlı bir fark varken, duygusal zekası yüksek olan grupta ise fark olmadığını göstermektedir, $F_{D Z D G}(3,3347)=5,32, p<0.01$; FDZYG $(3,2371)=3,30$. Scheffe testinin sonuçlarına göre, duygusal zekası düşük olan grupta hiç sahip olmayanların $(X=407,64), 1$ adet e-kitap okuyucuya sahip olanlara $(X=400,84), 2$ adet e-kitap okuyucuya sahip olanlar $(X=381,01)$ ve 3 ve daha fazla tablet bilgisayara sahip olanlarin $(X=$ 471,74), 2 adet e-kitap okuyucuya sahip olanlara $(X=366,87)$ göre fen bilimleri okuryazarlık ortalamalarının daha olumlu olduğu belirlenmiştir. Aslında e-kitap okuyucu sayısı fen bilimleri okuryazarlığına duygusal zekası yüksek ve düşük olan gruplarda olumsuz etki yapmıştır. Aslında toplum olarak teknolojik gelişmelere karşı ilgimiz varken, e okuyucuya karşı ilgi göstermemizin sebebi okumaya karşı ilgimizin yeterli olmadığından ve alışkanlıklarımız içerisinde yer almadığından kaynaklanıyor olabilir. Bu nedenle teknoloji, okumayı sevdirmek ve alışkanlık haline getirmek için kullanılabilir.

Tablo 10'da evinde e kitap okuyucu sayısına göre DZYG ile DZDG'un fen bilimleri okuryazarlığı arasında anlamlı bir farklılığın olup olmadığına yönelik bulgular yer almaktadır. 
Tablo 10. Öğrencilerin Fen Bilimleri Okuryazarlığı Ortalamasının Öğrencinin mezun olmak istediği eğitim düzeyine Göre ANOVA Sonuçları

\begin{tabular}{|c|c|c|c|c|c|c|c|c|c|}
\hline & Eğitim Düzeyi & $\mathrm{N}$ & $x$ & $\begin{array}{l}\text { Varyansın } \\
\text { kaynağ }\end{array}$ & $\mathrm{Sd}$ & $\begin{array}{c}\text { Kareler } \\
\text { Ortalaması }\end{array}$ & $\mathrm{F}$ & $\mathrm{p}$ & Fark \\
\hline \multirow{7}{*}{ DZYG } & Ortaokul (a) & 20 & 335,30 & Gruplararası & 4 & 414012,67 & \multirow{7}{*}{98,50} & \multirow{7}{*}{,00 } & \multirow{7}{*}{$\begin{array}{c}\text { e-d,e- } \\
\text { c,e- } \\
\text { b,e-a }\end{array}$} \\
\hline & Meslek ve & & & & & & & & \\
\hline & Meslek Öncesi & 289 & 393,29 & Gruplariçi & 2370 & 4203,14 & & & \\
\hline & Ortaöğretim (b) & & & & & & & & \\
\hline & Ortaöğretim (c) & 148 & 421,00 & Toplam & 2374 & & & & \\
\hline & Yüksekokul (d) & 130 & 416,66 & & & & & & \\
\hline & $\begin{array}{c}\text { Lisans ve } \\
\text { Lisansüstü (e) }\end{array}$ & 1788 & 461,05 & & & & & & \\
\hline \multirow{7}{*}{ DZDG } & Ortaokul (a) & 86 & 330,54 & Gruplararası & 4 & 595199,32 & & & \multirow{7}{*}{$\begin{array}{l}\text { e-d, } \\
\text { e-c,e- } \\
\text { b,e-a }\end{array}$} \\
\hline & Meslek ve & & & & & & & & \\
\hline & Meslek Öncesi & 626 & 365,47 & Gruplariçi & 3423 & 4310,99 & 138,07 & ,00 & \\
\hline & Ortaöğretim (b) & & & & & & & & \\
\hline & Ortaöğretim (c) & 260 & 391,16 & Toplam & 3427 & & & & \\
\hline & Yüksekokul (d) & 185 & 383,14 & & & & & & \\
\hline & $\begin{array}{c}\text { Lisans ve } \\
\text { Lisansüstü (e) }\end{array}$ & 2271 & 423,67 & & & & & & \\
\hline
\end{tabular}

$\mathrm{p}<0,01$

Analiz sonuçları, duygusal zekası yüksek ve düşük olan grubun fen bilimleri okuryazarlığı ortalaması ile mezun olmak istediği eğitim düzeyi açısından anlamlı bir fark olduğunu göstermektedir, $F_{\text {DZYG }}(4,2370)=98,50$; FDZDG $_{(4,3423)}=138,07$. Scheffe testinin sonuçlarına göre, duygusal zekası yüksek olan grupta lisans ve lisansüstü eğitimi almak isteyenlerin $(X=461,05)$, yüksekokul eğitimi almak isteyenlere $(X=416,66)$, ortaöğretim eğitimi almak isteyenlere $(X=421,00)$, meslek ve meslek öncesi eğitim almak isteyenlere $(X=393,29)$ ve ortaokul eğitimi almak isteyenlere $(X=335,30)$ göre fen bilimleri okuryazarlık ortalamalarının daha olumlu olduğu belirlenmiştir. Öğrencilere gelecek adına hedefler koymaları ve bu hedefleri gerçekleştirmelerine olanak tanınmalı ve yol gösterilmelidir.

\section{Tartışma}

PISA'nın öğrenci anketinde yer alan soruların tamamını cevaplayan öğrencilerin fen bilimleri okuryazarlığı ortalamaları, cevaplandırmayana göre daha olumludur. Anketin tamamını cevaplayan öğrencilerin soruları sabırla okuması sonra cevaplandırması, stres ile başa çıkması, sınav kaygısını kontrol etmesi, sınav esnasında konsantre olması gibi birden fazla duyguların kontrol ettiği için öğrencilerin duygusal zekasının yüksek olduğu belirtilebilir. Bu durum duygusal zekası yüksek olan bireylerin de fen bilimleri 
okuryazarlığının yüksek olduğunun sonucu ulaşılmıştır. Bu nedenle başarıda öğrencilerin duygularının da önemli olduğu ve bu önemin anlaşılması gerekliliği ortaya çıkmaktadır (Han ve Johnson, 2012). Ayrıca duygusal zekası yüksek olan öğrencilerin kişisel sınav endişesi ve motivasyonu, duygusal zekası düşük olanlara göre daha yüksek olduğu sonucuna ulaşılmıştır. Başka bir araştırma da öğrencilerin sınav kaygısının akademik başarıyı olumlu etkilediği belirtilirken (Ergene, 2011); sınav kaygısının başarıyı negatif etkilediğini belirten araştırma da yer almaktadır (Yıldırım, 2000). Bir başka çalışmada ise öğrencilerin akademik başarısını etkileyen en önemli faktörlerden birinin motivasyon olduğu belirlenmiştir (Sarıer, 2016). Bir başka çalışma da ise öğrencinin matematik motivasyonu ile matematik dersi arasında pozitif ilişki varken, sınav kaygısı ile matematik dersi akademik başarısı arasında negatif bir ilişki olduğu belirlenmiştir (Bozkurt ve Bircan, 2015).

Duygusal zekası yüksek ve düşük olan grupta ev ödevleri için bilgisayara ve internete sahip olan öğrencilerin fen bilimleri okuryazarlığı, sahip olmayanlara göre daha olumludur. Ancak dikkat çekici sonuç ise duygusal zekası yüksek olan grupta ev ödevleri için bilgisayar ve internet bulundurmayanların fen bilimleri okuryazarlığı ortalamaları, duygusal zekası düşük olan grupta ev ödevleri için bilgisayar ve internet bulunduranlara göre daha olumludur. Aslında bilgisayar ve internet bulundurma fen bilimleri okuryazarlığını arttırsa da duygusal zekası gelişmiş olan bireyler, evinde bilgisayarı ve interneti daha bilinçli bir şekilde kullandığı için internet bulundurmanın fen bilimleri okuryazarlığına etkisinin daha fazla olduğu ifade edilebilir. Bu durumu destekler diğer bir sonuç ise duygusal zekası yüksek olan grubun fen bilimleri okuryazarlığı ortalamasının evinde eğitim yazılımı bulunma durumuna göre anlamlı bir farklılık gösterirken duygusal zekası düşük olan grupta ise anlamlı bir farklılık yoktur. Bu sonuçlar doğrultusunda öğrencilere teknoloji odaklı fen eğitimlerinden önce teknolojinin nasıl ve hangi amaçla kullanması gerekliliğine yönelik duyguların gelişimine destek verilmelidir.

Analiz sonuçları, duygusal zekası yüksek ve düşük olan grubun fen bilimleri okuryazarlığı ortalaması ile internet bağlantılı telefon, bilgisayar ve tablet sayısı açısından anlamlı bir fark olduğunu göstermektedir. Ancak duygusal zekası yüksek ve düşük grupların fen bilimleri okuryazarlığı ortalamaları kıyaslandığında duygusal zekası yüksek olan grubun daha fazla olduğu görülmektedir. İnternet bağlantılı telefonun sayısında olduğu gibi bilgisayar ve tablet sayısı arttıkça aile fertlerinin her biri bu araçlarla olan etkileşim süresini arttırdığı için bu durumda daha fazla bilgiye ulaşılmasına imkân sağlanmakta ve fen bilimleri 
okuryazarlığı artmaktadır. Bir diğer sonuca göre duygusal zekası düşük olan grubun fen bilimleri okuryazarlığı ortalaması ile e-kitap okuyucu sayısı açısından anlamlı bir fark varken, duygusal zekası yüksek olan grupta ise fark olmadığını sonucuna ulaşılmıştır. Ayrıca, duygusal zekası yüksek ve düşük olan gruplarda e-kitap okuyucu sayısı arttıkça fen bilimleri okuryazarlığı olumsuz bir şekilde etkilenmiştir. Teknolojik gelişmelerle ilgili bir toplum olarak, e-kitap okuyucuya karşı ilgi göstermememizin sebebi okumaya karşı ilgimizin yeterli olmadığından ve alışkanlıklarımız içerisinde okumaya yer vermediğimizden kaynaklanıyor olabilir. Bu nedenle teknoloji, öğrencilere okumayı sevdirmek ve alışkanlık haline getirilmek için de kullanılabilir. Bu çalışmaya benzer çalışmalarda da öğrencilerin bilişim teknolojilerine olan yatkınlığının fen performansının kuvvetli bir yordayıcı olduğu hem evde hem de okulda bu teknolojilerin kullanıldığı ifade edilmektedir (Delen ve Bulut, 2011). Bir başka çalışmada da öğrencilerin fen bilimleri okuryazarlığı ile bilgisayar bulunduranların ve telefon sayısı fazla olanların arasında anlamlı bir fark olduğu bulunmuştur (Kaya ve Doğan, 2016).

$\mathrm{Bu}$ sonuçların yanında diğer bir sonuç da duygusal zekası yüksek ve düşük olan grubun fen bilimleri okuryazarlığı ortalaması ile mezun olmak istediği eğitim düzeyi açısından anlamlı bir fark olduğudur. Aslında öğrencilere gelecek adına hedefler koymaları ve bu hedefleri gerçekleştirmelerine olanak tanınmalı ve yol gösterilmelidir. Benzer durum öğrencilere teknoloji kullanmaya ve geliştirmeye yönelik hedefler ve amaçlar kazandırılmalı bu doğrultuda onlara yol gösterilmelidir. Bu durum onların teknolojiye karşı duygusal zekalarını geliştirmeye de imkan sağlayabilir. Bu sayede duygusal zekası yüksek olan bireyler, kendilerini tanır ve ihtiyaçlarını bilir, güçlü ve zayıf yanlarının farkında olur, duygularını kontrol etmeyi başarır ve etkili ilişkiler kurabilir (Tetik ve Açıkgöz, 2013). Aslında duyguların kontrolü, zaten bilişin ve onun bir parçası olan zekânın işidir (Erkuş, 2015). Ancak bir öğrenci başarılı olmak için duygularını işe koşması ve bu doğrultuda sorumluluk alması gerekir. Baş'a (2010) göre araştırma sonunda, Çoklu Zeka Kuramına uygun olarak ders yapılan sınıf başarısının ve İngilizce dersine karşı tutumunun, geleneksel öğretim yöntemleriyle ders işlenen sınıfın başarı ve derse yönelik tutumundan anlamlı düzeyde yüksek olduğu görülmüştür. Bu çalışmayı destekler başka bir çalışmada da Çoklu Zekâ Kuramı uygulamalarının öğrencilerin derse yönelik tutumları ve kalıcılığı açısından etkili olduğu görülmüştür (Uzunöz, 2010). Duyguların akademik başarı düzeyi ve öğrenme niteliğini arttırıcı bir etki yaptığı söylenebilir. 


\section{Sonuç ve Öneriler}

$\mathrm{Bu}$ çalışma da duygusal zekanın sınıflandırılması kanıtsal bir veriye dayalı olmayıp kuramsal bir sayıltıdan yola çıkılarak gerçekleştirilmiştir. Araştırma sonucuna göre de duygusal zekası yüksek olan bireylerin; motivasyonunun ve fen bilimleri okuryazarlığının daha yüksek olması, duyguların fen bilimleri okuryazarlığında pozitif etkisi olduğu sonucuna ulaştırır. Ayrıca bireylerin hem kendi duygularının farkında olup duygularını kontrol etmesi hem de eğitim düzeyi hedeflerini daha ileriye taşıması fen bilimleri okuryazarlığını daha fazla pozitif yönde etkilediği sonucuna ulaştırmaktadır.

Öğrencilerin evde bilişim teknolojisine sahip olması ve bunların niceliksel olarak artışı fen bilimleri okuryazarlığını etkilemektedir. Duygularının farkında olan ve bunları kontrol edebilen (duygusal zekası yüksek olan) bireylerin bu teknolojik araçları beklentileri doğrultusunda kullandıklarında fen bilimleri okuryazarlığının daha yüksek olduğu gözlemlenmektedir. Bu nedenle bilişim teknolojilerinin (bilgisayar, tablet, e-kitap okuyucu ve internet bağlantılı telefonlar) kullanımına yönelik öğrencilerin bilişsel ve duygusal olarak hazır bulunuşluk düzeyleri arttırılmalıdır. Ayrıca bu araçların nasıl ve ne şekilde kullanılması gerekliliği öğrencilere beceri boyutunda kazandırılmalıdır. Bu nedenle bilişim teknolojileri ile ilişkili dersler öğrencilere aktarılırken, duyguları işin içine katarak teknoloji kullanımına yönelik farkındalık oluşturulmalıdır. Öğrencilerin gelecekte daha fazla bilgisayar tabanlı sınavlarla başarıları ölçüleceği ve değerlendirileceği için bilgisayar tabanlı sınavlara karşı motivasyonları arttırılmalı ve sınav kaygılarının aşırısından uzak durulması için öğrencilere yardımcı olunmalıdır. Kişilerarası duygu paylaşımına imkan sağlayacak, iletişimi ve duyguları güçlendirecek okul kültürü oluşturulmalıdır. Ayrıca öğrencilere temel eğitim süreci içerisinde geleceğe dair teknoloji ile ilgili vizyonlar ve hedefler kazandırılmalıdır. Örneğin, gelecekte öğrenciler tercih edeceği meslek grubu teknoloji ile ilişkili (elektrik, elektrikelektronik, makine veya bilgisayar mühendisi gibi) ise teknolojinin onlar için bir amaç; bir öğretmenin dersinin etkinliğini arttırırken kullanılacaksa bunun araç olarak kullanmanın farkındalığı oluşturulmalıdır.

Fatih Projesi kapsamında bilişim teknolojileri aracılığıyla (özellikle tablet ve e-kitap okuyucuları) okuma alışkanlığı kazandırılması için projeler ve etkinlikler gerçekleştirilebilir. Hatta projenin ismi E-OKU(R) (Etkileşimli Okur ve Okuryazar) gibi ilgi çekici de olabilir. Bu konuda EBA platformunda kaynak zenginliği oluşturularak öğrenciler desteklenebilir. Öğrencilerin ilgilerini çekecek, duygu paylaşımına imkan verecek yazılar, hikayeler veya 
kitaplar teknolojik ortamlara aktarılarak öğrencilerin okuma alışkanlığı kazanması desteklenmelidir. Bu nedenle yazılımcı, dil bilimci ve alanında uzman kişilerin işbirliğine ihtiyaç vardır. Hatta dersleri disiplinlerarası ilişkilendirerek okumaya yönelik etkinlikler arttırılabilir.

\section{Kaynaklar}

Akgündüz, D. \& Ertepınar, H. (2015). Stem Eğitimi Türkiye Raporu "Günün Modası mı Yoksa Gereksinim mi?", İstanbul Aydın Üniversitesi STEM Merkezi ve Eğitim Fakültesi, DOI: 10.13140/RG.2.1.1980.0801.

Arlı, D., Altunay, E. \& Yalçınkaya, M. (2011). Öğretmen Adaylarında Duygusal Zekâ, Problem Çözme ve Akademik Başarı İlişkisi, Akademik Bakış Dergisi, Sayı:25.

Baş, G. (2010). İngilizce Dersinde Çoklu Zekâ Yaklaşımının Öğrencilerin Akademik Başarılarına Ve Derse Yönelik Tutum Düzeylerine Katkıları, e-Journal of New World Sciences Academy, Volume: 5, Number: 2, Article Number: 1C0138.

Bozkurt, E. \& Bircan, M.A. (2015). İlköğretim Beşinci Sınıf Öğrencilerinin Matematik Motivasyonları ile Matematik Dersi Akademik Başarıları Arasındaki İlişkinin İncelenmesi, Uluslararası Türk Eğitim Dergisi, Ekim Sayısı, 201-220.

Büyükalan Filiz, S. \& Kaya, V. H. (2013). Examine the Relationship Between the Curriculum of Science and Technology Course in Elementary Education and the Curriculum of Undergraduate and Graduate Programs of Science Teacher Education in Terms of Philosophy, Goal and Content., Journal of Turkish Educatinal Science, 11 (2), 185-208.

Büyüköztürk, S., Kılıç Çakmak, E., Akgün, Ö. E., Karadeniz, S. \& Demirel, F.(2008). Bilimsel Arastırma Yöntemleri, Pegem Akademi Yayıncılık, Ankara.

Chuan, L. T. (2016). View: Pisa Ranking does not Predict Future Success in Life, Erişim Adresi: http://www.tnp.sg/news/views/view-pisa-ranking-does-not-predict-future-successlife, Erişim Tarihi: 27.07.2017, 10.13.

Davie, S. (2013). Scaling Education Hights in PISA, Erişim Adresi: http://www.straitstimes.com/singapore/scaling-education-heights-in-pisa, Erişim Tarihi: 27.07.2017, 10.19.

Delen, E. \& Bulut, O. (2011). The Relationship Between Students' Exposure To Technology and Their Achievement In Science and Math, TOJET: The Turkish Online Journal of Educational Technology, volume 10 Issue 3. Sayfa. Eğerki e-kaynaksa e adresini belirtin

EBA. (2016). Eğitim Bilişim Ağı, Erişim Adresi: http://www.eba.gov.tr/hakkimizda, Erişim Tarihi: 6.01.2016, 11.48.

Ege, B. (2014). 4. Sanayi Devrimi Kapıda mı?Bilim ve Teknik Dergisi, Mayıs, 2014 Sayısı, Sayfa 26-29.

Ergene, T. (2011). Lise Öğrencilerinin Sınav Kaygısı, Çalışma Alışkanlıkları, Başarı Güdüsü ve Akademik Performans Düzeyleri Arasındaki İlişkilerin İncelenmesi, Eğitim ve Bilim Dergisi, Cilt 36, Sayı 160.

Erkuş, A. (2015). Düşünce Yazısı-Opınıon Paper "Nitel” ve Türevleri ("Alternatif ölçme", “Çoklu" ve "Duygusal zekâ"): Ne, Niçin ve Nereye Doğru?illköğretim Online, 14(3), dy:1-17. 
Eryılmaz Toksoy, S. \& Akdeniz, A. R. (2015). Öğrencilerin Kuvvet ve Hareket Ünitesi ile İlgili Problemleri Çözerken Güçlük Çektikleri Noktaların İpucu Kartlarıyla Belirlenmesi, Ĕ̆itim ve Bilim, Cilt 40, Sayı 180, 343-362.

Godek Altuk, Y., Kaya, V. H., \& Bahceci, D. (2015), The Relationship Between Primary School Students' Scientific Literacy Levels and Scientific Process Skills, Cypriot Journal of Educational Sciences, 10(1), 03-11.

Yüksel, M. \& Geban, Ö. (2014). Duygusal Zekâ Düzeyi İle Akademik Başarı Arasındaki İlişkinin Belirlenmesine Yönelik Bir Çalışma, International Online Journal of Educational Sciences, 6 (1), 165-182.

Kaya, V.H. (2017). The Impact of Reading Skills on Science Literacy, Journal of National Education, Say1 215.

Kaya, V.H. \& Dogan, A. (2017). Determination \& Comparison of Turkish Student Characteristics Affecting Science Literacy In Turkey According To PISA 2012, Research Journal of Business and Management, Vol 4, Issue 1, P.34-51, DOI: 10.17261/Pressacademia.2017.369 RJBM-V.4-ISS.1-2017(4)- p.34-51. w

Kaya, V. H. \& Dogan, A. (2016). Determination and Comparison of Turkish Student Characteristics Affecting Science Literacy in Turkey According to PISA 2012, International Conference on Quality in Higher Education Proceeding Book, Sakarya, Turkey.

Kaya, V. H., Polat, D. \& Kaya, E. (2014). The Primary School Teachers' Perception in the Investigation of the Effect on the Subject of Astronomy in The Observatory Activities (Sample of Ankara), 11th National Science and Mathematics Education Congress, Nigde, TURKEY.

Kaya, V. H. \& Kazancı, E. (2009), Ekolojik Okuryazarlık, Bilim ve Teknik Dergisi- yıldız takımı eki, Sayı 11, 14-15.

Kayri, H. (2009).Araştırmalarda Gruplar Arası Farkın Belirlenmesine Yönelik Çoklu Karşılaştırma (Post-Hoc) Teknikleri, Fırat Üniversitesi Sosyal Bilimler Dergisi, Cilt: 19, Say1: 1, Sayfa: 51-64.

Millı̂ Eğitim Bakanlı̆̆ı. (2016a). Eğitimde FATïH Projesi Hakkında, Erişim Adresi: http://fatihprojesi.meb.gov.tr/proje-hakkinda/, Erişim Tarihi: 6.01.2016, 11.48.

Millî Eğitim Bakanlığı. (2016b). STEM Eğitim Raporu,Yenilik ve Eğitim Teknolojileri Genel Müdürlüğü, Ankara.

Mohzan, M.AM., Hassan, N. \& Halil, N.A. (2013). The Influence of Emotional Intelligence on Academic Achievement, Procedia - Social and Behavioral Sciences , 90 , 303-312.

OECD (2016), PISA 2015 Results (Volume I): Excellence and Equity in Education, PISA, OECD Publishing, Paris. Erişim Adresi: http://dx.doi.org/10.1787/9789264266490-en, Erişim Tarihi: 26.12.2016.

Ogundokun, M.O. \&Adesem, D.A. (2010). Emotional Intelligence and Academic Achievement: The Moderating Influence of Age, Intrinsic and Extrinsic Motivation, The African Symposium, Vol. 10, No:2, 127-141.

Roy, B., Sinha, R. \& Suman, S. (2013). Emotional Intelligence And Academic Achievement Motivation Among Adolescents: A Relationship Study, International Refereed Research Journal, Vol. - IV, Issue - 2, 126-130. 
Uzunöz, A. (2010). Orta Öğretim Dokuzuncu Sınıf Coğrafya Dersinde Çoklu Zekâ Destekli Öğretimin Öğrenci Tutumu Ve Kalıcılığa Etkisi, e-Journal of New World Sciences Academy, Volume: 5, Number: 4, Article Number: 1C0222.

Üzel, D. \& Hangül, T. (2012). Duygusal Zekâ Ve Akademik Başarı Arasındaki İlişki, X. Ulusal Fen Bilimleri ve Matematik Eğitimi Kongresi, Niğde.

Polat, D., Gödek, Y. \&Kaya, V.H., (2016). According to PISA 2012, The Determination of the Relationship Between Mathematical Literacy and Mathematical Content Knowledge and Science Literacy: Turkey Sample, International Conference on Quality in Higher Education Proceeding Book, Sakarya, Turkey.

Polat, D., Gödek, Y., \& Kaya, V.H. (2017). According to PISA 2012, The Determination of the Relationship Between Mathematical Literacy and Mathematical Content Knowledge and Science Literacy: Turkey Sample, Research Journal of Business and Management, Vol 4, Issue 1, P.84-89, DOI: 10.17261/Pressacademia.2017.373 RJBM-V.4-ISS.1-2017(8)-p.8489.

Salovey, P. \& Mayer, J. (1990). Emotional intellegence. Imagination, Cognition and Personality, 9, (3), 185-211.

Sarıer, Y. (2016). Türkiye' de Öğrencilerin Akademik Başarısını Etkileyen Faktörler: Bir Metaanaliz Çalışması, Hacettepe Üniversitesi Eğitim Fakültesi Dergisi, DOI:10.16986/HUJE.2016015868.

Selçuk, Z., Palancı, M., Kandemir, M. \& Dündar, H. (2014). Eğitim ve Bilim Dergisinde Yayınlanan Araştırmaların Eğilimleri: İçerik Analizi, Eğitim ve Bilim, Cilt. 39, Sayı 173, 430-453.

Somuncuoğlu, D.(2005). Duygusal Zekâ Yeterliliklerinin Kuramsal Çerçevesi Ve Eğitimdeki Rolü, Kazım Karabekir Ĕ̆itim Fakültesi Dergisi, 11, 270-293.

Şahin, A., Ayar, M. C. \& Adıgüzel, T. (2014). Fen, Teknoloji, Mühendislik ve Matematik İçerikli Okul Sonrası Etkinlikler ve Öğrenciler Üzerindeki Etkileri, Kuram ve Uygulamada Ĕ̆itim Bilimleri, 14(1), 297-322.

Tabachnick, B. G., \&Fidell, L. S. (2001). Using multivariate statistics (Fourth edition). New York: Harper Collins Publishers.

Tetik, S. \& Açıkgöz, A. (2013). Duygusal Zekâ Düzeyinin Problem Çözme Becerisi Üzerindeki Etkisi: Meslek Yüksekokulu Öğrencileri Üzerine Bir Uygulama, Electronic Journal Of Vocational Colleges- Aralık 2013 Umyos Özel Sayı.

Titrek, O. (2016). IQ'dan EQ'ya: Duyguları Zekice Yönetme, Pegem Akademi Yayıncılık, Ankara

Gliner, J. A., Morgan, G. A. \& Leech, N. L. (2015). Research Methods In Applied Settings An Integrated Approach To Design and Analysis (S. Turan, Çev.), Nobel Yayınc1lık, Ankara.

Villavicencio, F.T. \& Bernardo, A.B.I. (2013). Positive Academic Emotions Moderate the Relationship Between Self-Regulation and Academic Achievement, British Journal of Educational Psychology, 83, 329-340.

Yahaya, A., Bachok, J., Yahaya, N. , Boon, Y. , Hashim, S. \& Lee, G. M. (2012). The Impact of Emotional Intelligence Element on Academic Achievement, Archives Des Sciences Vol 65, No. 4, 2-17. 
Yelkikalan, N. (2006). 21.Yüzyılda Girişimcinin Yeni Özelliği: Duygusal Zekâ, Girşimcilikve Kalkınma Dergisi, Cilt 1, Sayı 2, 39-51.

Yeşilyaprak, B. (2001). Duygusal Zekâ ve Eğitim Açısından Doğurguları, Kuram ve Uygulamada Eğitim Yönetimi, Sayı 25, Ss 139-146.

Yıldırım, A. \& Şimşek, H. (2003). Sosyal Bilimlerde Nitel Araştırma Yöntemleri. Ankara: Seçkin Yayınları.

Yıldırım, İ. (2000). Akademik Başarının Yordayıcısı Olarak Yalnızlık, Sınav Kaygısı ve Sosyal Destek, Hacettepe Üniversitesi Ĕ̆itim Fakültesi Dergisi,18: 167 - 176.

Yılmaz Karabulutlu, E., Yılmaz, S. \& Yurttaş, A. (2011). Öğrencilerin Duygusal Zekâ Düzeyleri ile Problem Çözme Becerileri Arasındaki İlişki, Psikiyatri Hemşireliği Dergisi ,2(2):75-79. 